\title{
HUBUNGAN ANTARA KONSEP DIRI (BODY IMAGE) DENGAN TINGKAT KECEMASAN PADA WANITA MENOPAUSE DI DESA MOTOLING II
}

\author{
Rina Kundre \\ Rivelino S Hamel \\ Program studi Ilmu Keperawatan Fakultas Kedokteran \\ Universitas Sam Ratulangi \\ Email : rina_kundre@yahoo.com
}

\begin{abstract}
Menopause is the last period or during the last menstrual period, one of the psychological aspects of a change in self-concept in the menopausal period is that menopausal women become worried about their bodies and form self-concept about how their bodies are. One of the psychological aspects of changing self-concept during menopause is that menopausal women become anxious about their bodies and form self-concepts about how their bodies are, maybe they look in the mirror every day and sometimes every hour.Research purposes This is to find out the relationship between self-concept and the level of anxiety during menopause in Motoling II Village. Research design the one used is descriptive correlation sampling technique that is by simple random method using two subjects of inclusion and exclusion with a lot of samples of 30 people. Research result using the chi-square test obtained between the self-concept and the level of anxiety in menopause $p$ value $=0.001<\alpha=0.005$. Conclusion the results of this study indicate that there is a relationship between self-concept and anxiety level during menopause in Motoling II Village. Suggestion expected for Health workers in the Village Motoling II to pay more attention to women in Motoling II Village, especially women who are approaching menopause so there will be no lack of knowledge about what is meant by menopause.
\end{abstract}

Keyword:The concept of self, levels of anxiety, Menopause

\begin{abstract}
Abstrak : Menopause adalah haid terakhir atau saat terjadi haid terakhir, salah satu aspek psikologis dari perubahan konsep diri dimasa menopause sudah pasti wanita menopause menjadicemas mengenai tubuh mereka dan membentuk konnsep diri mengenai bagaimana keadaan tubuh mereka. Salah satu aspek psikologis dari perubahan konsep diri dimasa menopause sudah pasti wanita menopause menjadi cemas mengenai tubuh mereka dan membentuk konsep diri mengenai bagaimana keadaan tubuh mereka, mungkin mereka melihat kedalam cermin setiap hari dan kadang setiap jam. Tujuan Penelitian ini untuk mengetahui hubungan antara konsep diri dengan tingkat kecemasan pada masa menopause di Desa Motoling II. Desain Penelitian yang digunakan yaitu bersifat deskriptif kolerasi teknik pengambilan sampel yakni dengan cara simple random dengan menggunakan dua subjek inklusi dan ekslusi dengan banyak sampel 30 orang Hasil Penelitian mengguanakan uji chi-square didapat antara Konsep diri dengan tingkat Kecemasan pada masa menopause nilai $p=0,001<\alpha=0,005$. Simpulan hasil penelitian ini menunjukan terdapat hubungan antara konsep diri dengan tingkat kecemasn pada masa menopause di Desa Motoling II Saran diharapkan bagi tenagah Kesehatan yang ada diDesa Motoling II agar lebih berperan aktif dalam meningkatkan pengetahuan wanita menopause supaya mengetahui dan menyadari perubahan yang terjadi.
\end{abstract}

Kata Kunci : Konsep diri, Tingkat kecemasan, Menopause 


\section{PENDAHULUAN}

Menopause menyebabkan beberapa perubahan, di antara yang terpenting adalah otak. Di dalam otak juga terjadi perubahan pada masa pramenopause seperti tubuh yang memanas, otak pun akan tersulut, terpicu oleh perubahanperubahan hormonal yang khas dalam transisi menopause, sehingga terjadilah suatu perubahan yang memberi sinyal pada perubahan-perubahan dalam cupingcuping temporal area otak yang terkait dengan intuisi yang meningkat (Northrupz, 2006).

Menopause alami akan dilalui seorang perempuan secara bertahap selama beberapa tahun. Umumnya menopause alami terjadi pada usia diakhir 40 tahun atau diawal 50 tahun. Menopause buatan adalah menopause yang terjadi akibat prosedur medis seperti pembedahan atau penyinaran.Menopause akibat pembedahan terjadi akibat histerektomi dan ooforektomi bilateral. Pengangkatan ovarium dilakukan sebagai tindakan preventif terhadap karsinoma ovarium (Sastrawinata, 2008).

Konsep diri adalah bagian darikonsep diri yang mencakup sikap dan pengalaman yang berkaitan dengan tubuh, termasuk pandangan tentang maskulinitas dan feminintas, kegagahan fisik, daya tahan, dan kapabilitas. Konsep diri berkembang secara bertahap selama beberapa tahun sejalan dengan seseorang wanita menopause mengenai tubuh dan struktur mereka, fungsi, kemampuan, dan keterbatasan mereka. Konsep diri dapat berubah dalam beberapa jam, hari, minggu, atau bulan, bergantung pada stimuli eksternal pada tubuh dan perubahan aktual dalam penampilan, struktur atau fungsi. Cara orang lain melihat tubuh kita juga mempunyai pengaruh (Potter \& Perry, 2005).

Kecemasan yang muncul pada wanita menjelang menopause sesering dihubungkan dengan adanya kekhawatiran dalam menghadapi suatu situasi yang sebelumnya tidak pernah dikhawatirkan. Padahal masa menopause merupakan masa yang alamiah dalam proses penuaan. Masa yang penting dalam kehidupan wanita, perubahan fungsi tubuh dapat mempengaruhi berbagai macam kehidupannya baik dalam kehidupan sosial, perasaan tentang dirinya, dan fungsi di dalam pekerjaan (Pieter, 2010).

Beberapa keluhan fisik yang merupakan tanda dan gejala dari menopause adalah menstruasi menjadi tidak teratur, hot flushes, insomnia, palpitasi dan rasa lemah, gangguan seksual. Gejala-gejala saluran kemih seperti nyeri saat berkemih, infeksi saluran kemih dan inkontinensia (Glasier \&Gebbie, 2005).

Berdasarkan ciri-ciri fisik dan psikologis dari sindrom menopause adalah Menstruasi berhenti, Sistem reproduksi menurun dan berhenti, Penampilan kewanitaan menurun, Ketidaknyamanan fisik, Berat badan bertambah, Penonjolan, Perubahan kepribadian (Jahja, 2011)

Hasil data awal pada wawancara yang dilakukan didesa Motoling dua sebanyak 5 responden yang didapat yakni responden memiliki riwayat menopause dengan karakteristik yang berhubungan antara konsep diri dengan tingkat kecemasan pada wanita menopause dengan keluhan saat wawancara karena kurang pengetahuan tentang menopause sehingga muncul kecemasan pada dirinnya sendiri tentang perubahan yang terjadi saat menjelang menopause dan sering muncul rasa malu karna tidak bisa menahan kencing saat bercengkrama dengan tetangga, mudah tersinggung dan susah tidur dimalam hari, Hal tersebut yang timbul pada wanita menopause di Desa Motoling II.

Berdasarkan uraian di atas, maka penulis tertarik pada permasalahan menopause ini. Untuk itu, penulis ingin melakukan penelitian terkait dengan Hubungan antara konsep diri (Body Image) dengan tingkat kecemasan pada 
wanita menopause di Desa Motoling II Kecamatan Motoling.

\section{METODE PENELITIAN}

Penelitian ini bertujuan untuk mengidentifikasi konsep diri wanita masa menopause, mengidentifikasi tingkat kecemasan wanita masa menopause, dan mengidentifikasi hubungan antara konsep diri dengan tingkat kecemasan ibu masa menopause. Desain penelitian yang digunakan dalam penelitian ini adalah bersifat deskriptif korelasi, yaitu desain penelitian atau penelaahan hubungan antara dua variabel atau lebih pada situasi atau kelompok sampel (Notoatmodjo, 2010).

Populasi dalam penelitian ini adalah semua wanita yang berusia 45-50 tahun yang telah memasuki masa menopause di Desa Motoling II sejumlah 30 responden.Hasil Sampel pada wanita menopasue sebanyak 30 orang wanita masa menopause di Desa Motoling II Kecamatan Motoling. Instrument yang digunakan penelitian untuk mendapatkan informasi tentang variable independent dan dependent yaitu untuk data Konsep diri dan tingkat kecemasan yaitu dengan menggunakan kuesioner disusun peneliti berdasarkan tinjaian pustaka sedangkan kuesioner tingkat kecemasan disusun dengan berpedoman pada Hamilton Rating Scale for Anxiety (HRS-A) yang bertujuan untuk mengidentifikasi tingkat kecemasan ibu masa menopause.

Data yang telah dikumpulkan selanjutnya dilakukan pengolahan melalui tahap editing, coding, scoring dan tabulating. Analisis data menggunakan analisis univariat dan bivariat. Analisa bivariat mengunakan Uji chi-square namun karena hasil melebihi cell maka ditambahakan hasil alternative yaitu uji Kolmogorov-Smirnov dengan proses perhitungan menggunakan aplikasi komputer progam.

\section{HASIL dan PEMBAHASAN}

Data umum hasil penelitian yaitu terdiri dari karakterisrik responden berdasarkan umur dan pendidikan.

Tabel 1. Distribusi Frekuensi Responden Menurut Usia

\begin{tabular}{lcc}
\hline \multicolumn{1}{c}{ Umur } & $\mathrm{n}$ & $\%$ \\
\hline$>45$ tahun & 27 & 90.0 \\
$\leq 45$ tahun & 3 & 10.0 \\
\hline Total & 30 & 100 \\
\hline
\end{tabular}

Sumber : Data Primer 2017

Tabel 1. diatas yang menjelaskan distribusi data umur dari responden dan yang paling banyak adalah rentang usia > 45 tahun yaitu sebanyak 27 responden atau 90,0\%.

Tabel 2. Distribusi Frekuensi Responden Menurut Pendidikan

\begin{tabular}{lcc}
\hline Pendidikan & $\mathrm{n}$ & $\%$ \\
\hline SD & 3 & 10,0 \\
SMP & 7 & 23,3 \\
SMA & 13 & 43,3 \\
PT & 5 & 16,7 \\
TS & 2 & 6,7 \\
\hline Total & 30 & 100 \\
\hline
\end{tabular}

Sumber : Data Primer 2017

Tabel 2. diatas menjelaskan bahwa dengan kategori tingkat pendidikan sebagian besar berlatar belakang Sekolah Menengah Atas (SMA) yakni sebanyak 13 orang atau 43,3\% dan terendah pada Tidak Sekolah ( TS) 2 orang atau 6,7\%. Data Analisis Univariat selanjutnya yaitu Konsep diri dan tingkat kecemasan.

Tabel 3. Distribusi Frekuensi Responden Menurut Konsep Diri

\begin{tabular}{ccc}
\hline Konsep Diri & $\mathrm{n}$ & $\%$ \\
\hline Konsep Diri Baik & 18 & 60,0 \\
Kurang Baik & 12 & 40,0 \\
\hline Total & 30 & 100,0 \\
\hline
\end{tabular}

Sumber : Data Primer 2017 
Tabel 3. diatas menjelaskan bahwa Konsep Diri penduduk di Desa motoling Dua baik yaitu sebanyak 18 responden atau 60,0 .

Tabel 4. Distribusi Frekuensi Responden Menurut Tingkat Kecemasan

\begin{tabular}{lcc}
\hline \multicolumn{1}{c}{ Tingkat Kecemasan } & $\mathrm{n}$ & $\%$ \\
\hline Tidak ada Kecemasan & 8 & 26,6 \\
Kecemasan Ringan & 10 & 33,3 \\
Kecemasan Sedang & 7 & 3,3 \\
Kecemasan Berat & 5 & 16,7 \\
\hline Total & 30 & 100,0 \\
\hline
\end{tabular}

Sumber : Data Primer 2017

Tabel 4. diatas menjelaskan bahwa Tingkat Kecemasan pendudukdi Desa Motoling Dua mengalami kecemasan ringan sebanyak 10 orang atau $33,3 \%$

Tabel 5. Hubungan Konsep Diri dengan Tingkat Kecemasan pada Wanita Menopause

\begin{tabular}{|c|c|c|c|c|c|c|c|c|c|c|}
\hline \multirow[t]{3}{*}{ Konsep Diri } & \multicolumn{9}{|c|}{ Tingkat Kecemasan } & \multirow{3}{*}{$\begin{array}{c}P- \\
\text { Valu } \\
e\end{array}$} \\
\hline & \multicolumn{2}{|c|}{$\begin{array}{l}\text { Tidak Ada } \\
\text { Kecemasan }\end{array}$} & \multicolumn{2}{|c|}{ Ringan } & \multicolumn{2}{|c|}{ Sedang } & \multicolumn{2}{|c|}{ Berat } & \multirow{2}{*}{ Total } & \\
\hline & $\mathrm{n}$ & $\%$ & $\mathrm{n}$ & $\%$ & $\mathrm{n}$ & $\%$ & $\mathrm{n}$ & $\%$ & & \\
\hline Baik & 7 & 38.9 & 8 & 44.4 & 2 & 11.1 & 1 & 5.6 & 60.0 & \\
\hline Kurang Baik & 1 & 3.2 & 2 & 16.7 & 5 & 41.7 & 4 & 33.3 & 40.0 & 0,015 \\
\hline Total & 8 & 26.7 & 10 & 73.3 & 7 & 16.7 & 5 & 16.7 & 100.0 & \\
\hline
\end{tabular}

Sumber : Data Primer 2017

Tabel 5. diatas dengan hasil analisis Hubungan Konsep diri dengan Tingkat Kecemasan pada masa menopause di Desa Motoling II Kecamatan Motoling, dengan menggunakan uji chi-square diperoleh $P$-Value 0,015. Hal ini berarti nilai $\mathrm{p}$ lebih kecil dari $\alpha(0,05)$ maka dengan demikian dapat dikatakan bahwa Ho ditolak dan $\mathrm{Ha}$ diterima yang berartibahwa Terdapat Hubungan Konsep diri dengan Tingkat Kecemasan pada masa menopause di Desa Motoling II Kecamatan Motoling.

\section{Hubungan antara Konsep diri dengan tingkat kecemasan pada wanita menopause didesa Motoling II}

Hasil uji statistic chi-square yang didapat pada wanita menopause dapat disimpulkan yakni Konsep diri baik namun tidak memiliki kecemasan 7 responden $(36,9 \%)$ hal ini dikarenakan karena waanita menopause tersebut masih merasa percaya diri dengan dengan bentuk tubuhnya sehingga tidak merasa cemas dengna apa yang dialaminya saat menjelang masa menopause, hal ini juga diperkuat pada penelitian di desa Tlogo Suryo Kelurahan Tlogomas Malang Tahun 2012 tidak memiliki kecemasan yakni 10 responden $(33,3 \%)$ Banyak faktor dapat yang mempengaruhi gambaran diri seseorang, seperti munculnya stresor yang dapat mengganggu integrasi gambaran diri. Stresor-stresor tersebut seperti operasi, kegagalan fungsi tubuh, wahana yang berkaitan dengan bentuk dan fungsi tubuh, tergantung pada mesin, perubahan tubuh, umpan balik interpersonal yang negatif dan standard sosial budaya (Suliswati,2012).

Berdasarkan hasil yang didapat pada konsep diri kurang baik tidak memiliki kecemasan ada 1 responden $(8,3 \%)$ dan konsep diri baik dengan tingkat kecemasan ringan yang lebih banyak yakni 8 responden $(44,4 \%)$ dalam wawancara didapatkan bahwa wanita yang menjelang masa menopause tersebut memiliki konsep diri masih menerima kekurangan yang terjadi pada bentuk tubuhnya dan tetap berusaha membina hubungan dengan kerabat dan keluarga, namun firasat cemas serta takut akan pikiran sendiri dan ada keluarga dari responden mengatakan bahwa sering tersinggung dengan hal-hal kecil. Hal ini diperkuat dengan hasil penilitian yang dilakukan didesa Tlogo Suryo Kelurahan Tlogomas Malang bahwa tingkat kecemasan ringan lebih banyak pada tahun 2012. Potter \& Perry (2005) Banyak faktor yang mempengaruhi konsep diri seseorang seperti munculnya stressor, 
stressor tersebut dapat berupa perubahan tubuh, umpan balik intra personal yang negatif dan standar sosial budaya. Konsep diri kurang baik dan kecemasan ringan ada 2 responden $(16,7 \%)$ hasil wawancara yang didapat yakni merasa bahwa tubuhnya sudah tidak menarik lagi serta muka mulai kendor, seringkali menjadi pelupa atau menurunnya daya ingat.

Penelitian yang dilakukan pada desa Motoling II yang terdapat konsep diri baik dengan kecemasan yang sedang yakni 2 responden $(11,1 \%)$ dalam wawancara dilakukan pada responden yakni keduanya menjawab bahwa berubahan pada dirinya atau bentuk tubuh tidak mengurangi rasa percaya dirinya dalam beraktifitas, konsep diri kurang baik pada kecemasan sedang 5 responden $(41,7 \%)$ saat diwawancara yaitu responden menjawab kalau sering tidak merasa gesit dalam melakukan sesuatu dan mudah terkecing saat ingin tertawa atau terlalu cepat melakukan sesuatu muka merasa merah namut bibir terasa kering dan pucat.

Bentuk yang sangat disayangkan yang jarang didengar oleh orang, didapatkan hasil didesa Motoling II bahwa dalam wawancara yang didapat pada konsep diri baik dengan tingkat kecemasan berat yakni 4 responden $(33,3 \%)$ dan konsep diri kurang baik dngan tingkat kecemasan berat 1 responden $(5,6 \%)$ yakni ada responden yang menjawab bahwa mereka kurang percaya diri dan merasa tidak dibutuhkan lagi saat terjadi pertengkaran dengan keluarga (Suami) karena sudah tidak bisa lagi memiliki keturunan sehingga kecemasan dan kegelisaan muncul pada dirinya hasil penilitian yang dilakukan didesa Tlogo Suryo Kelurahan Tlogomas Malang bahwa tingkat kecemasan juga terjadi atau dialami saat masa menopause. Perilaku individu akan sesuai dengan cara individu memandang dirinya sendiri. Apabila individu memandang dirinya sebagai orang yang tidak mempunyai cukup kemampuan untuk melakukan suatu tugas tertentu, maka seluruh perilakunya akan menunjukkan ketidakmampuannya tersebut. Cemas mengandung arti pengalaman psikis yang biasa dan wajar, yang pernah dialami setiap orang dalam rangka memacu individu untuk mengatasi masalah yang sedang dihadapi sebaik baiknya (Hawari, 2006).

\section{SIMPULAN}

Berdasarkan hasil penelitian dan pembahasan, maka dapat ditarik kesimpulan sebagai berikut:

1. Konsep diri pada wanita menopause lebih banyak pada konsep diri baik .

2. Tingkat kecemasan pada wanita menopause lebih banyak pada kecemasan ringan.

3. Ada hubungan konsep diri dengan tingkat kecemasan pada ibu masa menopause di Desa Motoling Dua.

\section{DAFTAR PUSTAKA}

Glasier A dan Gebbie, A. 2006.Keluarga Berencana dan Kesehatan Reproduksi (Edisi 4) Cet. Pertama.Jakarta: EGC.

Hawari Dadang. 2006. Manajemen Stres, Cemas dan Depresi. Jakarta: Balai Penerbit FKUI.

Jahja, Y. 2011. Psikologi Perkembangan. Jakarta: Kencana

Northrupz, C. 2006. Bijak disaat menopause-Menciptakan Kesehatan Fisik dan Emosional Saat Menghadapi Perubahan. Bandung: Q-Press

Notoadmodjo Soekidjo. 2010. Metodologi Penelitian Kesehatan. Jakarta : Rineka Cipta.

Pieter H. Z, \& Lumongga N. 2010. Pengantar Psikologi untuk Kebidanan. Jakarta: Kencana

Potter \& Perry. (2005). Fundamental Keperawatan: Konsep, Proses, dan Praktik. Jakarta: Penerbit Buku Kedokteran EGC. 
e-journal Keperawatan (e-Kp) Volume 7 No.1 13 Februari 2019

Suliswati dkk. 2012. Konsep Dasar

Keperawatan Kesehatan Jiwa. Jakarta:

EGC.

Sastrawinata S.2008. Wanita dalam

Berbagai Masa Kehidupan. dalam:

Wiknjosastro H, ed. Ilmu Kandungan

Edisi 2. Jakarta: Yayasan Bina

Pustaka Sarwono Prawirohardjo 